\title{
Stress Factors Impact on Pharmacist Job Satisfaction in Saudi Arabia
}

\author{
Yousef Ahmed Alomi* iD, The Former \\ General Manager of General Administration \\ of Pharmaceutical Care, Former Head, \\ National Clinical Pharmacy and Pharmacy \\ Practice, Former Head, Pharmacy R\&D \\ Administration, Ministry of Health, Riyadh, \\ SAUDI ARABIA. \\ Faiz A. Bahadig Rph, Informatics Phar- \\ macist, Pharmaceutical Care Department, \\ King Abdul-Aziz Medical, City-WR-Jeddah, \\ Ministry of National Guard, SAUDI ARABIA. \\ Khurram Shahzad, Senior Pharmacist, \\ Pharmaceutical Care Department, King \\ Abdul-Aziz Medical City-Jeddah, Ministry of \\ National Guard, SAUDI ARABIA. \\ Saima Qaism, Senior Pharmacist, Pharma- \\ ceutical Care Department, King Abdul-Aziz \\ Medical City-Jeddah, Ministry of National \\ Guard, SAUDI ARABIA. \\ Budoor Emad Aloumi, Pharmacist, \\ Pharmaceutical Care Services, Ministry of \\ National Guard - Health Affairs. KAMC - \\ Central Region, SAUDI ARABIA. \\ Bayan Ibrahim Alghuraybi, Pharmacy \\ Services, Prince Sultan Military Medical City, \\ Riyadh, SAUDI ARABIA. \\ Reem Saad Alsubaie, Pharmacy Services, \\ Prince Sultan Military Medical City, Riyadh, \\ SAUDI ARABIA.
}

\section{Correspondence:}

Yousef Ahmed Alomi, (Bsc. Pharm, MSc. Clin Pharm, BCPS, BCNSP, DiBA, CDE) The Former General Manager of General Administration of Pharmaceutical Care, Former Head, National Clinical Pharmacy and Pharmacy Practice, Former Head, Pharmacy R\&D Administration, Ministry of Health, Riyadh, SAUDI ARABIA.

Phone no: +966 504417712

E-mail:yalomi@gmail.com

Received: 15-03-2019;

Accepted: 28-05-2019

Copyright: $\odot$ the author(s),publisher and licensee Pharmacology, Toxicology and Biomedical Reports. This is an open-access article distributed under the terms of the Creative Commons Attribution NonCommercial License, which permits unrestricted non-commercial use, distribution, and reproduction in any medium, provided the original work is properly cited.

This is an open access article distributed under the terms of the Creative Commons Attribution-NonCommercial-ShareAlike 4.0 License

\begin{tabular}{|l|l|}
\hline \multicolumn{2}{|c|}{ Access this article online } \\
\hline & www.ptbreports.org \\
\cline { 2 - 2 } & \\
\hline
\end{tabular}

\begin{abstract}
Purpose: To explore the stress factors impact of pharmacist job satisfaction in Saudi Arabia. Methods: It is a 4-months cross section survey of the stress factors impact of pharmacist job satisfaction in Saudi Arabia. The study consisted of 44 questions divided into two-part demographic information and the second part was the questions about stress related factors of pharmacy job. It included pharmacy management policies, pharmacy stress factors, pharmacy personal time, salary and benefits, pharmacy motivation factors, overall job satisfaction. The 5-points Likert response scale system closed ended questions were used. Results: The total responders were 242. Of those 214 (91.8\%) was Saudi and 33 (8.2\%) was non-Saudi. The gender distribution 169 (70.7\%) 55.8\%) was male and 70 (29.3\%) was female. The average pharmacist satisfaction score of pharmacy management policies factors was (3.53), personal pharmacy time was (3.14) and salary and benefits were (2.45) as explored in Table 4. The average score of pharmacy stress factors were (3.86) and the overall job satisfaction was (3.61) as explored in Table 5. The most pharmacy motivation factors found were the financial reward and salary advancement was $201(87.01 \%)$, followed by the time needed for education and training was 144 $(62.3 \%)$ and flexibility in work scheduling was $136(58.87 \%)$ as explored in Table 6. Conclusion: The majority of pharmacists suffered from pharmacy salary and benefits and time demand for development and education. Those factors were essential of motivation factors related to the pharmacy job satisfaction in Saudi Arabia.

Keywords: Stress, Factors, Job, Satisfaction, Pharmacy, Saudi Arabia.
\end{abstract}

\section{INTRODUCTION}

Several pharmacy practice programs implemented in the period 2012-2015 including Pharmacy administration program. ${ }^{1,2}$ That's including patient satisfaction of pharmacy services, pharmacist job satisfaction and pharmacist interventions. ${ }^{3,4}$ The pharmacist job satisfaction consisted of several elements communication of pharmacist, the pharmacist stress and motivation factors and pharmacy service factors. ${ }^{5-7}$ Several publications have been released about stress factors, other studies about motivations factors. ${ }^{7-9}$ Most of the studies involved community pharmacists or hospital pharmacists while some of them included both community and hospital pharmacists. ${ }^{5,7-10}$ Some of publications were review reports and the majority of them were cross sectional studies. ${ }^{5,-14}$ Most of the investigations were international while few studies done locally and other few publish from Middle East countries. ${ }^{5,7,9,10,14-16}$ Two of Saudi studies and one from Jordan on job satisfaction were done with community pharmacist and two studies consisted of hospital pharmacists. Based on best of the knowledge, the authors not familiar with more investigations in Kingdom of Saudi Arabia or Gulf countries done with hospital pharmacists of pharmacy technicians. The aim of the current study was to explore pharmacy job satisfaction and related management policies, stress and motivations factors in Saudi Arabia.

\section{METHODS}

It is a 4-months cross section survey of the stress factors impacting pharmacist job satisfaction in Saudi Arabia. The study consisted of 44 questions divided into two-part demographic information and the second part was the questions about stress related factors of pharmacy job. It included pharmacy management policies, pharmacy stress factors, pharmacy personal time, salary and benefits, pharmacy motivation factors, overall job satisfaction. The 5-points Likert response scale system closed ended questions were used. The questionnaire was made as an electronic format and it analyzed through survey monkey system.

\section{RESULTS}

The total responders were two hundred and forty-two. Of those $214(91.8 \%)$ was Saudi and 33 $(8.2 \%)$ was non-Saudi. The gender distribution $169(70.7 \%) 55.8 \%)$ was male and $70(29.3 \%)$ was female. The majority of them $202(84.2 \%)$ were in age group (20-39). The most of pharmacists were married $152(66.38 \%)$ while 75 (32.75\%) were singles (Table 1). The most educational level of the responders was pharmacy bachelor degree $114(47.7 \%)$, followed by pharmacy diploma level was 81 (33.89\%) and Pharm.D 26 (10.88\%). Most of the responders has not board of pharmaceuticals 171 (93.44\%). Most were at the current position of pharmacy technician 80 (34.93\%) and staff pharmacist $78(34.5 \%)$ and worked at outpatient pharmacy 83 (39.7\%) and inpatient pharmacy $73(34.9 \%)$. The most the responders 
spent less than $72(30 \%)$, followed by three years three to five years 61 $(24.42 \%)$ and six to ten years $50(20.83 \%)$ worked in the current position. While more of responders receive 7,000-12,000 SR monthly salary 138 (58.97\%) (Table 2). Most of the responders worked at Ministry of health 103 (42.92\%) followed by MOH government Hospital 66 (27.5\%) and Non- MOH government Hospital 31 (12.92\%). Most of the responders worked at (200-299 beds) 32 (17.02\%) followed by (100-199 beds) $31(16.49 \%)$ and (<50 beds) 29 (15.43\%). Most of the hospitals were accredited by Saudi Commission for Health Specialties 97 (48.74\%) followed by Saudi Central Board for Accreditation of Healthcare Institutions (CBAHI) 58 (29.15\%) and Joint commission of hospital accreditations USA 40 (20.1\%) (Table 3). The average pharmacist satisfaction score of pharmacy management policies factors was (3.53), personal pharmacy time was (3.14) and salary and benefits were (2.45) (Table 4). The average score of pharmacy stress factors were (3.86) and the overall job satisfaction was (3.61) (Table 5). The most pharmacy motivation factors found were the financial reward and salary advancement was 201 (87.01\%), followed by the time needed for education and training was 144 (62.3\%) and flexibility in work scheduling was 136 (58.87\%) (Table 6).

\section{DISCUSSION}

During early of the 2010s the pharmacy strategic plan at the Ministry of Health released. ${ }^{1,2}$ Several measures for elements of performance indicators were founded to follow up plan implementation. ${ }^{2}$ Of those critical indicators was Pharmacist job satisfaction. The current study was a part to measure indicators of job satisfaction. The findings of the investigation showed the pharmacist satisfaction of job satisfaction is not ade-

Table 1: Demographic social information.

\begin{tabular}{|l|c|c|}
\hline Nationality & Response Count & Response Percent \\
\hline Saudi & 214 & 91.85 \\
\hline Non- Saudi & 19 & 8.15 \\
\hline Answered question & 233 & \\
\hline Skipped question & 9 & \\
\hline Gender & Response Count & Response Percent \\
\hline Male & 169 & 70.71 \\
\hline Female & 70 & 29.29 \\
\hline Answered question & 239 & \\
\hline Skipped question & 3 & \\
\hline Age & Response Count & Response Percent \\
\hline$<19$ & 0 & 0 \\
\hline $20-29$ & 87 & 42.08 \\
\hline $30-39$ & 86 & 12.92 \\
\hline $40-49$ & 26 & 2.92 \\
\hline $50-59$ & 6 & 0 \\
\hline$>60$ & 0 & \\
\hline Answered question & 240 & \\
\hline Skipped question & 229.75 \\
\hline Marital status & 132 & \\
\hline Single & & \\
\hline Married & & \\
\hline Other (please specify) & & \\
\hline Answered question & & \\
\hline Skipped question & & \\
\hline
\end{tabular}

Table 2: Demographic responder qualifications information.

\begin{tabular}{|c|c|c|}
\hline Academic Qualification (s): & $\begin{array}{l}\text { Response } \\
\text { Count }\end{array}$ & $\begin{array}{c}\text { Response } \\
\text { Percent }\end{array}$ \\
\hline Diploma Pharmacy & 81 & 33.89 \\
\hline Bsc. Pharm & 114 & 47.70 \\
\hline M.S & 4 & 1.67 \\
\hline Msc. Clinical Pharmacy & 16 & 6.69 \\
\hline Pharm.D. & 26 & 10.88 \\
\hline Ph.D & 2 & 0.84 \\
\hline MBA & 4 & 1.67 \\
\hline Pharmacy Residency Two years (R2) & 2 & 0.84 \\
\hline Pharmacy Residency one year (R1) & 2 & 0.84 \\
\hline Fellowship & 0 & 0 \\
\hline Other (please specify) & 3 & 1.26 \\
\hline Answered question & 239 & \\
\hline Skipped question & 3 & \\
\hline Board of Pharmaceutical Specialty & $\begin{array}{l}\text { Response } \\
\text { Count }\end{array}$ & $\begin{array}{c}\text { Response } \\
\text { Percent }\end{array}$ \\
\hline $\begin{array}{l}\text { Board Certified Ambulatory Care Pharmacist } \\
\text { (BCACP) }\end{array}$ & 2 & 1.09 \\
\hline $\begin{array}{l}\text { Board Certified Critical Care Pharmacist } \\
\text { (BCCCP) }\end{array}$ & 3 & 1.64 \\
\hline Board Certified Nuclear Pharmacist (BCNP) & 0 & 0.00 \\
\hline $\begin{array}{l}\text { Board Certified Nutrition Support Pharmacist } \\
\text { (BCNSP) }\end{array}$ & 0 & 0.00 \\
\hline $\begin{array}{l}\text { Board Certified Oncology Pharmacist } \\
\text { (BCOP) }\end{array}$ & 0 & 0.00 \\
\hline $\begin{array}{l}\text { Board Certified Pediatric Pharmacy Specialist } \\
\text { (BCPPS) }\end{array}$ & 0 & 0.00 \\
\hline $\begin{array}{l}\text { Board Certified Pharmacotherapy Specialists } \\
\text { (BCPS) }\end{array}$ & 2 & 1.09 \\
\hline $\begin{array}{l}\text { Board Certified Psychiatric Pharmacist } \\
\text { (BCРP) }\end{array}$ & 1 & 0.55 \\
\hline Non & 171 & 93.44 \\
\hline Other (please specify)) & 4 & 2.19 \\
\hline Answered question & 183 & \\
\hline Skipped question & 59 & \\
\hline Current position & $\begin{array}{c}\text { Response } \\
\text { Count }\end{array}$ & $\begin{array}{c}\text { Response } \\
\text { Percent }\end{array}$ \\
\hline Pharmacy Technicians & 80 & 34.93 \\
\hline Lecturer & 0 & 0.00 \\
\hline Intern Pharmacist & 3 & 1.31 \\
\hline Director of Pharmacy & 22 & 9.61 \\
\hline Staff Pharmacist & 79 & 34.50 \\
\hline Supervisor Pharmacist & 21 & 9.17 \\
\hline Clinical Pharmacist & 12 & 5.24 \\
\hline Deputy Director of Pharmacy & 4 & 1.75 \\
\hline Manager & 3 & 1.31 \\
\hline Other (please specify) & 5 & 2.18 \\
\hline Answered question & 229 & \\
\hline Skipped question & 13 & \\
\hline
\end{tabular}




\begin{tabular}{|c|c|c|}
\hline The practice area & $\begin{array}{c}\text { Response } \\
\text { Count }\end{array}$ & $\begin{array}{c}\text { Response } \\
\text { Percent }\end{array}$ \\
\hline Inpatient Pharmacy & 73 & 34.76 \\
\hline Outpatient Pharmacy & 83 & 39.52 \\
\hline Satellite Pharmacy & 0 & 0.00 \\
\hline Narcotics & 2 & 0.95 \\
\hline Extemporaneous Preparation & 2 & 0.95 \\
\hline Clinical Pharmacy & 9 & 4.29 \\
\hline Inventory Control & 3 & 1.43 \\
\hline Drug Information & 4 & 1.90 \\
\hline Emergency pharmacy & 2 & 0.95 \\
\hline Medication safety & 2 & 0.95 \\
\hline Repacking & 0 & 0.00 \\
\hline Pharmacy Education and Training & 1 & 0.48 \\
\hline Other (please specify) & 29 & 13.81 \\
\hline Answered question & 210 & \\
\hline Skipped question & 32 & \\
\hline Total years you worked in current position & $\begin{array}{c}\text { Response } \\
\text { Count }\end{array}$ & $\begin{array}{c}\text { Response } \\
\text { Percent }\end{array}$ \\
\hline$<3$ & 72 & 30.00 \\
\hline 3-5 & 61 & 25.42 \\
\hline $6-10$ & 50 & 20.83 \\
\hline $11-15$ & 25 & 10.42 \\
\hline$>15$ & 32 & 13.33 \\
\hline Answered question & 240 & \\
\hline Skipped question & 2 & \\
\hline Monthly income & $\begin{array}{c}\text { Response } \\
\text { Count }\end{array}$ & $\begin{array}{c}\text { Response } \\
\text { Percent }\end{array}$ \\
\hline$<6.000$ & 16 & 6.84 \\
\hline $7.000-9.000$ & 56 & 23.93 \\
\hline $10.000-12.000$ & 82 & 35.04 \\
\hline $14,000-16,000$ & 43 & 18.38 \\
\hline $18,000-20,000$ & 26 & 11.11 \\
\hline$>25.000$ & 11 & 4.70 \\
\hline Answered question & 234 & \\
\hline Skipped question & 8 & \\
\hline Reasons for taking time off work & $\begin{array}{c}\text { Response } \\
\text { Count }\end{array}$ & $\begin{array}{c}\text { Response } \\
\text { Percent }\end{array}$ \\
\hline Illness & 169 & 74.12 \\
\hline Education & 46 & 20.18 \\
\hline Don't feel you like to work & 19 & 8.33 \\
\hline Not satisfied with the work & 56 & 24.56 \\
\hline Other (please specify) & 29 & 12.72 \\
\hline Answered question & 228 & \\
\hline Skipped question & 14 & \\
\hline
\end{tabular}

quate with similar finding with previous studies ${ }^{9,10,17-19}$ and better than what reported by other study due other factors affected the pharmacist in the study. ${ }^{5}$ That's related several factors list them in the discussion. The level of satisfaction of pharmacy management policies is not reached the optimal level. Most of the pharmacist had workload is excessive and there is not enough staff to cover all pharmacy related activities with similar finding with previous study ${ }^{14}$ and different from other community pharmacist study satisfied with high workload that's related to low workload and free time at the pharmacy without benefit. Most of the responders were taking time off due to illness. Is that due to real diseases, or they were escaping from the work. The high workload with a shortage of staff is maybe expected because there is a very significant shortage of pharmacy staff at Ministry of Health institutions during regular days or during providing pharmacy services to the pilgrims at hospitals or primary care centers. Other factors that may affect pharmacist's satisfaction was personal pharmacy time with inadequate scoring satisfaction. That's

Table 3: Demographic hospital information.

\begin{tabular}{|c|c|c|}
\hline Sector of work & $\begin{array}{c}\text { Response } \\
\text { Count }\end{array}$ & $\begin{array}{c}\text { Response } \\
\text { Percent }\end{array}$ \\
\hline Ministry of Health & 103 & 42.92 \\
\hline General Medical Directorate in Region & 3 & 1.25 \\
\hline MOH government Hospital & 66 & 27.50 \\
\hline Non- MOH government Hospital & 31 & 12.92 \\
\hline MOH-Primary Care Center & 22 & 9.17 \\
\hline Private Hospital & 3 & 1.25 \\
\hline Private Primary Care Center & 0 & 0 \\
\hline Community pharmacy & 7 & 2.92 \\
\hline Other (please specify) & 5 & 2.08 \\
\hline Answered question & 240 & \\
\hline Skipped question & 2 & \\
\hline Number of beds at your hospital & $\begin{array}{l}\text { Response } \\
\text { Count }\end{array}$ & $\begin{array}{c}\text { Response } \\
\text { Percent }\end{array}$ \\
\hline$<50$ & 29 & 15.43 \\
\hline $50-99$ & 16 & 8.51 \\
\hline 100-199 & 31 & 16.49 \\
\hline 200-299 & 32 & 17.02 \\
\hline 300-399 & 15 & 7.98 \\
\hline $400-499$ & 13 & 6.91 \\
\hline 500-599 & 14 & 7.45 \\
\hline$=$ or $>600$ & 13 & 6.91 \\
\hline Medical City & 25 & 13.30 \\
\hline Answered question & 188 & \\
\hline Skipped question & 54 & \\
\hline The hospital accreditation & $\begin{array}{l}\text { Response } \\
\text { Count }\end{array}$ & $\begin{array}{c}\text { Response } \\
\text { Percent }\end{array}$ \\
\hline CBAHI & 58 & 29.15 \\
\hline Joint Commotion USA & 40 & 20.10 \\
\hline Canada & 4 & 2.01 \\
\hline Saudi commission of health accreditation & 97 & 48.74 \\
\hline Answered question & 199 & \\
\hline Skipped question & 43 & \\
\hline
\end{tabular}


Table 4: The pharmacist satisfaction of management policies, Personal time and Salary and benefits.

\begin{tabular}{|c|c|c|c|c|c|c|c|c|}
\hline & $\begin{array}{l}\text { Overall management } \\
\text { policies }\end{array}$ & 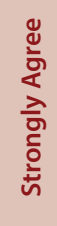 & ॠँّ & 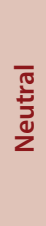 & 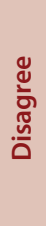 & 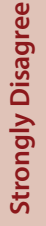 & 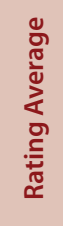 & 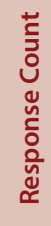 \\
\hline 1 & $\begin{array}{l}\text { I am allowed a sufficient } \\
\text { amount of freedom to } \\
\text { decide how I do my } \\
\text { work. }\end{array}$ & 38 & 72 & 69 & 36 & 23 & 3.28 & 238 \\
\hline 2 & My workload is excessive. & 105 & 76 & 40 & 17 & 2 & 4.10 & 240 \\
\hline 3 & $\begin{array}{l}\text { Staffing is inadequate; } \\
\text { not enough employees } \\
\text { are hired to cover the } \\
\text { workload. }\end{array}$ & 124 & 59 & 32 & 19 & 6 & 4.15 & 240 \\
\hline 4 & $\begin{array}{l}\text { The managemen, in } \\
\text { scheduling work hours at } \\
\text { my place of employmen, } \\
\text { takes into account } \\
\text { individual employee } \\
\text { needs and preferences. }\end{array}$ & 24 & 74 & 69 & 42 & 30 & 3.08 & 239 \\
\hline 5 & $\begin{array}{l}\text { I work too many } \\
\text { weekend and holiday } \\
\text { hours }\end{array}$ & 35 & 67 & 63 & 56 & 19 & 3.18 & 240 \\
\hline 6 & $\begin{array}{l}\text { My environmental } \\
\text { working conditions } \\
\text { (lighting, air conditionin, } \\
\text { heating, bathroom } \\
\text { facilities, ventilation, } \\
\text { noise level, etc.) are poor. }\end{array}$ & 66 & 59 & 41 & 49 & 24 & 3.39 & 239 \\
\hline & Average & & & & & & 3.53 & \\
\hline \multicolumn{9}{|c|}{ Answered question 240, Skipped question 2} \\
\hline & $\begin{array}{l}\text { Personal time and } \\
\text { related issues }\end{array}$ & 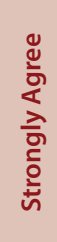 & 巡 & 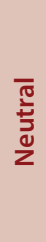 & 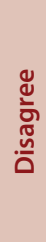 & 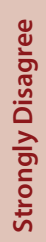 & 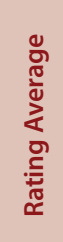 & 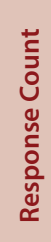 \\
\hline 1 & $\begin{array}{l}\text { I have the time to focus } \\
\text { on continuing education } \\
\text { and maintain my } \\
\text { professional competence }\end{array}$ & 15 & 44 & 44 & 66 & 66 & 2.47 & 235 \\
\hline 2 & $\begin{array}{l}\text { I have the time to take } \\
\text { breaks during the day. }\end{array}$ & 7 & 70 & 48 & 67 & 46 & 2.68 & 238 \\
\hline 3 & $\begin{array}{l}\text { My work has a significant } \\
\text { contribution to the } \\
\text { successful operation of } \\
\text { my organizatio. }\end{array}$ & 44 & 79 & 71 & 27 & 15 & 3.47 & 236 \\
\hline 4 & $\begin{array}{l}\text { I am able to positively } \\
\text { influence patient drug } \\
\text { therapy. }\end{array}$ & 52 & 121 & 55 & 5 & 3 & 3.91 & 236 \\
\hline
\end{tabular}

\begin{tabular}{|c|c|c|c|c|c|c|c|c|}
\hline 5 & $\begin{array}{l}\text { Compared with the } \\
\text { respect shown to other } \\
\text { health professionals, } \\
\text { patients and customers } \\
\text { show pharmacists an } \\
\text { appropriate amount of } \\
\text { respect. }\end{array}$ & 20 & 88 & 57 & 49 & 21 & 3.16 & 235 \\
\hline & Average & & & & & & 3.14 & \\
\hline \multicolumn{9}{|c|}{ Answered question 238, Skipped question 4} \\
\hline & Salary and benefits & 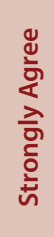 & 芩 & 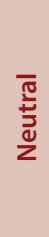 & 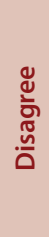 & 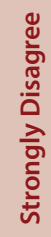 & 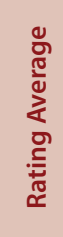 & 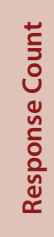 \\
\hline 1 & $\begin{array}{l}\text { Considering the kind } \\
\text { of work, I do and the } \\
\text { amount of responsibility } \\
\text { I have, my pay is about } \\
\text { right. }\end{array}$ & 8 & 48 & 34 & 84 & 67 & 2.36 & 241 \\
\hline 2 & $\begin{array}{l}\text { My salary is equivalent } \\
\text { to the salary of persons } \\
\text { holding similar positions } \\
\text { in other organizations. }\end{array}$ & 13 & 46 & 56 & 73 & 52 & 2.56 & 240 \\
\hline \multirow[t]{2}{*}{3} & $\begin{array}{l}\text { I am satisfied with my } \\
\text { salary. }\end{array}$ & 14 & 37 & 51 & 71 & 66 & 2.42 & 239 \\
\hline & Average & & & & & & 2.45 & \\
\hline
\end{tabular}

related there is no time to attend Pharmacy continuous medical education or continue postgraduate studies in the pharmacy Specialty with similar factor with previous study ${ }^{4}$ while not similar from other study due to community pharmacist subject. ${ }^{14}$ The factors that affected pharmacist job dissatisfaction most was the salary benefits from the pharmacy work with similar finding with previous study., ${ }^{47}$ That's related to not enough salary for pharmacist. Most of the responders were married and their monthly wage between 7,000-12,000 SR (1,866-3,200 USD) which not enough for pharmacist or pharmacy technicians and his wife. The stress factors of pharmacy job were the high workload and most of the pharmacists agreed that's the stress factors associated negatively affected the quality of work and adverse effected to the patients that's similar finding with previous study. ${ }^{20}$ The majority of motivations factors may raise the satisfaction on the Pharmacy job was the salary and financial reward similar to the previous study, ${ }^{19}$ and available of time to continue their Postgraduates education and training. Also, the reduction of pharmacy workload may improve pharmacist job satisfaction. ${ }^{21}$ Those factors are very critical to motivate pharmacy staff and remove dissatisfaction on Pharmacy job similar finding with previous study. ${ }^{15}$ The study is second done in Saudi Arabia with detail of factors affected pharmacy job satisfaction. Annual or every two years of investigation of pharmacy job satisfaction is highly recommended in the Kingdom of Saudi Arabia.

\section{CONCLUSION}

The most stress factors was affected on pharmacist job satisfaction was salary, benefits and shortage of pharmacy time for medical education. 
Table 5: The pharmacy stress factors and overall job satisfactions.

\begin{tabular}{|c|c|c|c|c|c|c|c|c|}
\hline & Pharmacy stress factors & 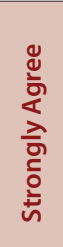 & ষ্ & 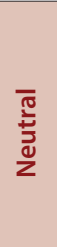 & 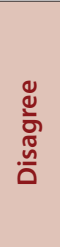 & 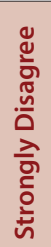 & 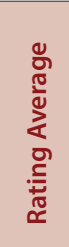 & 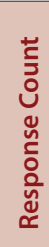 \\
\hline 1 & $\begin{array}{l}\text { The number of hours I } \\
\text { work is excessive. }\end{array}$ & 66 & 74 & 64 & 30 & 3 & 3.72 & 237 \\
\hline 2 & $\begin{array}{l}\text { The number of } \\
\text { prescriptions per day is } \\
\text { excessive. }\end{array}$ & 96 & 72 & 47 & 17 & 2 & 4.04 & 234 \\
\hline 3 & $\begin{array}{l}\text { The stress associated with } \\
\text { my job has adversely } \\
\text { affected my mental or } \\
\text { emotional health and } \\
\text { well-being. }\end{array}$ & 98 & 69 & 43 & 23 & 3 & 4.00 & 236 \\
\hline 4 & $\begin{array}{l}\text { The stress associated with } \\
\text { my job has adversely } \\
\text { affected the quality of the } \\
\text { work that I do. }\end{array}$ & 72 & 70 & 51 & 37 & 5 & 3.71 & 235 \\
\hline 5 & $\begin{array}{l}\text { The stress associated with } \\
\text { my job has adversely } \\
\text { affected my relationships } \\
\text { with friends and those } \\
\text { close to me. }\end{array}$ & 72 & 85 & 39 & 34 & 3 & 3.81 & 233 \\
\hline & Average & & & & & & 3.86 & \\
\hline \multicolumn{9}{|c|}{ Answered question 237, Skipped question 5} \\
\hline & Overall job satisfaction & 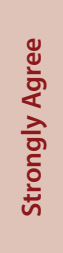 & ఖ & 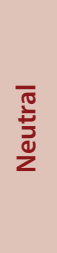 & 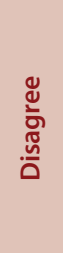 & 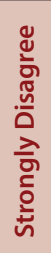 & 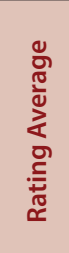 & 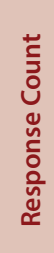 \\
\hline 1 & $\begin{array}{l}\text { I find challenge in my } \\
\text { work. }\end{array}$ & 87 & 100 & 32 & 16 & 6 & 4.02 & 241 \\
\hline 2 & $\begin{array}{l}\text { Knowing what I know } \\
\text { now, if I had to decide all } \\
\text { over again whether to go } \\
\text { into pharmacy, I would } \\
\text { choose another field. }\end{array}$ & 62 & 43 & 36 & 60 & 39 & 3.12 & 240 \\
\hline 3 & $\begin{array}{l}\text { If I were free to pursue } \\
\text { any type of career I } \\
\text { wanted, I would stay in } \\
\text { pharmacy. }\end{array}$ & 68 & 80 & 57 & 21 & 14 & 3.70 & 240 \\
\hline & Average & & & & & & 3.61 & \\
\hline
\end{tabular}

Targeting to start motivation elements included salary flexible schedule for medical education will raise pharmacist job satisfaction in the kingdom of Saudi Arabia.

\section{ACKNOWLEDGEMENT}

None.

\section{Table 6: The pharmacist's motivations factors.}

\begin{tabular}{|l|c|c|}
\hline $\begin{array}{l}\text { Suggest methods for motivating } \\
\text { Pharmacy practitioners }\end{array}$ & $\begin{array}{c}\text { Response } \\
\text { Count }\end{array}$ & $\begin{array}{c}\text { Response } \\
\text { Percent }\end{array}$ \\
\hline Financial rewards, salary advancements & 201 & 87.01 \\
\hline More favorable schedule & 118 & 51.08 \\
\hline Increased autonomy in the workday & 80 & 34.63 \\
\hline Flexibility in scheduling & 136 & 58.87 \\
\hline $\begin{array}{l}\text { Funds to support additional education } \\
\text { and training }\end{array}$ & 135 & 58.44 \\
\hline $\begin{array}{l}\text { Time off to achieve additional education } \\
\text { and training }\end{array}$ & 144 & 62.34 \\
\hline $\begin{array}{l}\text { Opportunity for advancement to } \\
\text { pharmacy management }\end{array}$ & 86 & 37.23 \\
\hline $\begin{array}{l}\text { Opportunity to teach/mentor pharmacy } \\
\text { students and residents }\end{array}$ & 79 & 34.20 \\
\hline Chances of promotion & 108 & 46.75 \\
\hline Increased pharmacy manpower & 5 & 2.16 \\
\hline Other (please specify) & 16 & 6.93 \\
\hline Answered question & 231 & \\
\hline Skipped question & 11 & \\
\hline
\end{tabular}

\section{CONFLICT OF INTEREST}

The authors declare that there are no conflicts of interest.

\section{ABBREVIATIONS}

KSA: Kingdom of Saudi Arabia; MOH: Ministry of Health; B.Sc. Pharm: Bachelor in pharmacy; Pharm D: Doctor of Pharmacy; CBAHI: Saudi Central Board for Accreditation of Healthcare Institutions.

\section{ORCID ID}

Yousef Ahmed Alomi iD https://orcid.org/0000-0003-1381-628X

\section{REFERENCES}

1. Alomi YA, Alghamdi SJ, Alattyh RA. Strategic Plan of General Administration of Pharmaceutical Care at Ministry of Health in Saudi Arabia 2012-2022. J Pharm Pharm Scien. 2015;1(13):1-8.

2. Alomi YA, Alghamdi SJ, Alattyh RA, Elshenawy RA. The evaluation of pharmacy strategic plan in Past 2013-2016 and forecasting of new vision 2030 at Ministry of Health in Saudi Arabia. J Pharm Pract Community Med. 2018;4(2):93-101.

3. Alomi Y. National Pharmacy Administration Programs. BAOJ Pharm Sci. 2015;1(2):1-2

4. Balkhi B, Alghamdi A, Alshehri N, Alshehri A. Assessment of job satisfaction among hospital pharmacists in Saudi Arabia. IOSR J Pharm. 2017;7(5):34-40.

5. Belay Y. Job satisfaction among community pharmacy professionals in Mekelle city, Northern Ethiopia. Adv Med Educ Pract. 2016;7:527-31.

6. Ahmad A, Khan MU, Elkalmi RM, Jamshed SQ, Nagappa AN, Patel I, et al. Job satisfaction among Indian pharmacists: An exploration of affecting variables and suggestions for improvement in pharmacist role. Indian J Pharm Educ Res. 2016;50(1):9-16.

7. Bonenberger M, Aikins M, Akweongo P, Wyss K. The effects of health worker motivation and job satisfaction on turnover intention in Ghana: A cross-sectional study. Hum Resour Health. 2014;12(1):1-12.

8. McCann L, Hughes CM, Adair CG, Cardwell C. Assessing job satisfaction and stress among pharmacists in Northern Ireland. Pharm World Sci. 2009;31(2):188-94.

9. Suleiman A. Stress and job satisfaction among pharmacists in Riyadh, Saudi Arabia. Saudi J Med Med Sci. 2015;3(3):213.

10. Maio V, Goldfarb NI, Hartmann CW. Pharmacists' Job satisfaction: Variation by practice setting. Pharm Ther. 2004;29(3):184-90.

11. Murawski MM, Payakachat N, Koh-Knox C. Factors affecting job and career satisfaction among community pharmacists: A structural equation modeling 
approach. J Am Pharm Assoc. 2008;48(5):610-20.

12. Kuiper RL, Cowan DLP, Pacitti R. Job satisfaction in hospital pharmacists. Am J Heal Pharm. 2011;68(2):115.

13. Bawazir SA. Job satisfaction in Saudi community pharmacists. J Pharm Pract Res. 2005;35(4):334

14. Zahrani F, Ghamdi M, Ahmad R. Job Satisfaction among Retail Pharmacists in Eastern Region of Saudi Arabia. J Pharm Res Int. 2017;19(5):1-12.

15. Slimane NSB. Motivation and Job Satisfaction of Pharmacists in Four Hospitals in Saudi Arabia. J Health Manag. 2017;19(1):39-72.

16. AlKhalidi D, Wazaify M. Assessment of pharmacists' job satisfaction and job related stress in Amman. Int J Clin Pharm. 2013;35(5):821-8.
17. Mengesha M, Tigabu BM. Job satisfaction of pharmacists in Ethiopia: The case of Harar town. Int J Pharm Pharm Sci. 2014;6(9):449-52.

18. Liu CS, White L. Key determinants of hospital pharmacy staff's job satisfaction. Res Soc Adm Pharm. 2011;7(1):51-63.

19. Benslimane N, Khalifa M. Evaluating pharmacists' motivation and job satisfaction factors in Saudi Hospitals. Stud Health Technol Inform. 2016;226:201-4.

20. Le HM, Young SD. Exploring the relationship between environmental stressors, pharmacy residents' stress and medication errors. J Psychol Cogn. 2017;2(3):192-7.

21. Lea VM, Corlett SA, Rodgers RM. Workload and its impact on community pharmacists' job satisfaction and stress: A review of the literature. Internationa Journal of Pharmacy Practice. 2012;20(4):259-71. 